\title{
Development of Cycling Tourism Model in Bonyoh Traditional Village, Kintamani District, Bangli Regency
}

\author{
I Nengah Suastika ${ }^{1}$, A. A. Istri Dewi Adhi Utami ${ }^{1}$. \\ nengah.suastika@undiksha.ac.id, adhi.utami@undiksha.ac.id \\ ${ }^{1}$ Universitas Pendidikan Ganesha, Indonesia
}

\begin{abstract}
This study aims to analyze the model of cycling tourism development in the Bonyoh Traditional Village. The research method used is a qualitative research method. Data collection techniques were carried out using participatory observation methods, interviews and document studies. The data analysis technique uses qualitative methods, starting with data collection, data reduction, data presentation and drawing conclusions based on their logical connection. The results of the analysis show that cycling tourism is under the management and ownership of the Bonyoh Traditional Village with the profits fully returned to all Bonyoh Traditional Village communities through the Traditional Village. The development of cycling tourism in Bonyoh Village is carried out in stages: (1) determining routes and analyzing route feasibility, (2) making cycling tourism maps in Bonyoh Village, (3) making cycling tour package menus in Bonyoh Village, (4) forming a management structure cycling tours in Bonyoh Village (5) create promotional media on social media and websites.

Keywords: development; cycling tours; traditional village
\end{abstract}

\section{Introduction}

Bicycles are a means of land transportation used to transport goods/people, recreational activities and sports. At first the bicycle was a means of transportation used to speed up the journey, facilitate the transportation of goods and valuables that indicated the strata of the owner [4]. The rapid development of transportation facilities then makes bicycles a means of transportation that is not widely used by the community. However, bicycles as a means of transportation then have a strategic role in building public health and fitness. Then the bicycle became an alternative transportation and sport to get to work in several countries. Cycling can provide various effects, such as speeding up travel, environmentally friendly transportation, doing sports activities that are healthy for the body, and making sports activities unnoticed (Lucía et al., 2003). These various advantages make cycling a sport activity that is always competed in various sporting events and used as a recreational activity for tourists in rural areas, especially in Bali. Cycling tourism activities are increasingly increasing the number of devotees, both domestic tourists and foreign tourists. This is due to several advantages of cycling tourism, namely: (1) cycling tours can be enjoyed by all ages, both children and the elderly, (2) presenting sports activities and tourist activities at the same time, (3) requiring relatively low costs. lighter than other tourism activities, and (4) offering natural panoramas, natural activities of rural community life and natural cultural attractions [9]. 
One of the bali aga villages that is currently developing cycling tourism is the Bonyoh Traditional Village. Bonyoh Traditional Village has enormous potential to become one of the cycling tourism destinations in Bali Province, especially in the Kintamani tourist area. It has beautiful rural landscapes, traditional rural spatial concepts, varied road models, ranging from dirt roads, asphalt roads to concrete rebate roads, towering mountainous landscapes, traditional community life that is natural, traditional community traditions unique and interesting, values of togetherness and mutual cooperation in various traditional and cultural activities, citrus plantations that stretch throughout the village area, traditional agricultural activities and various varieties of vegetable plants that are soothing to the eyes [11]. The very beautiful countryside scenery with the expanse of yellowing orange plants in the harvest season is the main attraction for tourists. The air is still cool to be an efficacious herbal medicine for tourists who go around riding bicycles while exercising.

Cycling tourism development is believed to be able to arouse farmers' efforts in structuring agricultural land, structuring agricultural crops, using environmentally friendly agricultural fertilizers and medicines, increasing farmers' work motivation, increasing the selling value of agricultural products, building post-harvest processing creativity, creating opportunities. additional work for the Bonyoh Traditional Village community and increase the income of the Bonyoh Traditional Village community [13]. Therefore, the community established this cycling tourism business under the ownership and management of the Bonyoh Traditional Village, so that the benefits obtained can be felt by all Bonyoh Traditional Village communities. This Traditional Village-based management model has not been widely used in tourism businesses in the Province of Bali [6]. However, until now the cycling tourism in the Bonyoh Traditional Village has not been able to be carried out by the manager. Theoretically and empirically, it shows that management models, staff, facilities, trekking and operational offices have been provided by the Bonyoh Traditional Village to be able to carry out tourism cycling activities in the Bonyoh Traditional Village. On the other hand, wiata cycling is one of the prima donna of tourist activities that are sought after by tourists, both domestic and foreign who visit Bali Province [3]. In this regard, this study examines the model for developing a cycling tourism business policy in the Bonyoh Indigenous Village community and the steps for developing cycling tourism in the Bonyoh Indigenous Village, Kintamani District. 


\section{Research methods}

This research is seen from the methodological aspect using qualitative research methods with a descriptive approach [1]. The location of this research is the Bonyoh Traditional Village, Kintamani District, Bangli Regency which has a cycling tourism business. The subjects of this study were the management of the Bonyoh Traditional Village, the manager of the cycling tourism business, community leaders and members of the community of the Bonyoh Traditional Village which were determined in a purposeful manner. The technique of withdrawing and developing research subjects was carried out purposively (purposive sampling technique), then the number and types were developed using a rolling "snowball sampling technique" until data saturation was achieved where information/data had been collected completely [8]. Data collection techniques were carried out by interviewing, observing and studying documents using interview guide research instruments, observation guidelines and document study guidelines [7]. Data processing and analysis techniques in this study will be carried out qualitatively, which begins with collecting data, sorting and selecting data, presenting the data as a whole based on their logical connection, then interpreted in the overall research context.

\section{Results and Discussion Model Development of Cycling Tourism Business Policy in the Bonyoh Traditional Village Community, Kintamani District}

As one of the Bali Aga Villages in Bali Province, Bonyoh Traditional Village has a very unique government system. In the social, cultural, agricultural, animal husbandry, customs and administration fields, it is led by a Kelian Desa Adat (customary village head) who is tasked with carrying out activities related to the administrative management of the Traditional Village [2]. The Kelian of the Bonyoh Traditional Village is directly elected by the male members of the Bonyoh Traditional Village community through a process of deliberation to reach consensus (sangkepan). For religious activities, the Bonyoh Traditional Village is led by Jero Kubayan (the head of the Bonyoh Traditional Village) who is determined based on the order of marriage (ulu apad). Ulu apad has the meaning of a leader who is determined based on his age, experience and anticipation of various problems that have been experienced during his life [10]. This ulu apad system provides adequate stages of learning for all members of the community before reaching the top leadership (Jero Kubayan), because they have to go through the levels below with different tasks and responsibilities. These stages are able to mature physically and spiritually, so that Jero Kubayan is considered the most sacred person in the Bonyoh Traditional Village in addition to having performed various kinds of self-cleaning ceremonies [2].

The decision-making process in the Bonyoh Traditional Village for non-religious activities is carried out by Kelian Adat with the approval of all members of the Bonyoh Traditional Village community [12]. In relation to the development of a cycling tourism business, the policy-making process begins with the proposal of community members to develop a tourist village. Based on the proposal from the community members, then the Kelian Desa Adat held a meeting with members of the Paruman Alit (small meeting) whose members consisted of the Kelian Desa Adat, the Representative of the Kelian Desa Adat, the Treasurer of the Traditional Village, Kelian Banjar Adat and Jero Kubayan to discuss the proposal for a cycling tourism business. . The results of this small meeting agreed on several things related to the development of tourism villages and cycling tourism businesses, namely: (1) the development of tourist villages in the Bonyoh Traditional Village must have a strong philosophical foundation to prevent the abrasion of culture, customs and traditions of the 
Bonyoh Traditional Village community during industry. tourism has developed in the future, (2) the development of tourist villages must be in line with the values, traditions, customs and culture as well as the empirical social conditions of the Bonyoh Traditional Village community, (3) the development of tourist villages is directed at efforts to strengthen the traditional customs and culture of the village community. Bonyoh Traditional Village [3], (4) tourism business developed in Bonyoh Traditional Village which is essential and controls the livelihood of the Bonyoh Traditional Village community is managed by the Traditional Village for the benefit of all members of the Bonyoh Traditional Village community, and (5) The cycling tourism business in the Bonyoh Traditional Village is under the management of the Traditional Village and the profits are fully obtained Yes, it is used for the benefit of all members of the Bonyoh customary village community.

The results of this meeting of Paruman Alit members were then conveyed to all members of the Bonyoh Indigenous Village community through deliberation to reach consensus. The purpose of this deliberation is to obtain input, advice and approval from all members of the Bonyoh Traditional Village community regarding the development of tourism villages and cycling tourism businesses. Responding to the results of the meeting of the members of the Paruman Alit meeting, all members of the Bonyoh Traditional Village community in principle agreed to develop a tourist village and a cycling tourism business in the Bonyoh Traditional Village. The suggestions given by community members related to the development of cycling tourism are: (1) involving experts from universities to create a sycling tourism business model, (2) the initial capital for the cycling tourism business is borne by the Bonyoh Traditional Village as the owner and manager of the business, (3) to reduce the burden of business capital, bicycles as initial capital are rented from the community by the Traditional Village when there are orders from tourists and the rental fee is adjusted to the ability of the cycling tourism business unit, (4) cycling tourism workers are recruited transparently through formal information from the Kelian Desa Adat Bonyoh, (5) cycling tourism workers must come from the Bonyoh Traditional Village to avoid problems in the future, and (6) maintaining the cleanliness and beauty of the traditional village and the Bonyoh Traditional Village area are the shared responsibility of all members of the Bonyoh Traditional Village community. The decision-making process for the development of cycling tourism is democratic with a sense of family and togetherness. This is evident with the unanimous decision of all communities to support the development of cycling tourism which was built in the village of existence.

\section{Steps for Cycling Tourism Development in Bonyoh Traditional Village, Kintamani District.}

The development of a cycling tourism business in Bonyoh Village is carried out in several stages, namely: (1) determining the route and analyzing the feasibility of the route, (2) making a cycling tourism map in Bonyoh Village, (3) creating a cycling tour package menu in Bonyoh Village, and (4 ) establish a cycling tourism management structure in Bonyoh Village. Conceptually, the steps for developing a cycling tourism business in Bonyoh Traditional Village can be described as follows: 


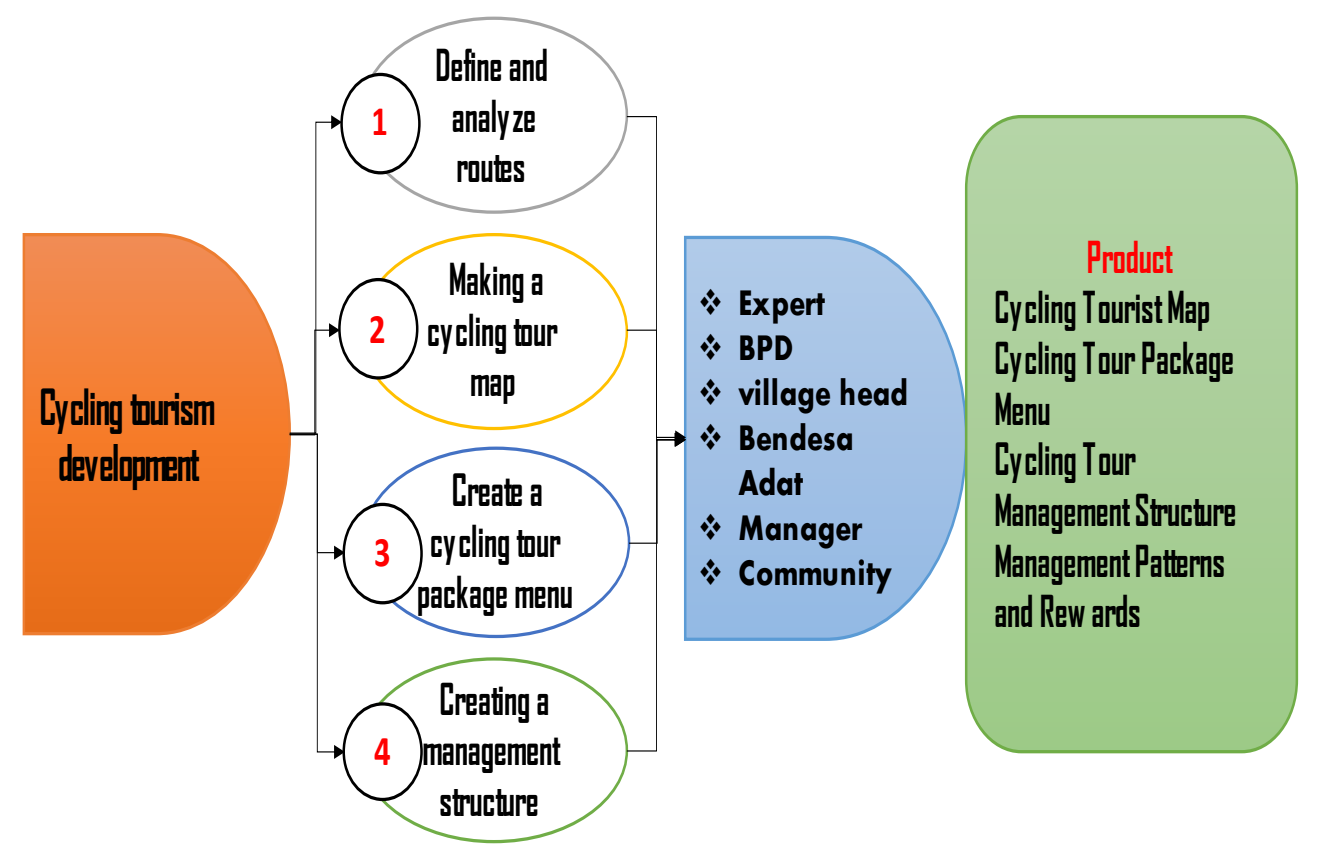

Figure 1. Cycling Tourism Development Process

The first stage is to analyze the cycling route by identifying and tracing all the roads in the Bonyoh Traditional Village. The analysis conducted found that there were three road models, namely asphalt roads, concrete rebate roads and dirt roads. These three roads can be traversed by all modes of transportation, namely cars, motorbikes and bicycles. Except for a few small alleys that cannot be passed by car, because the road is narrow even though it is flat. The roads in the Bonyoh Traditional Village pass through settlements, agricultural land or citrus plantations, and forests in the Bonyoh Traditional Village Area. The most interesting road routes traversed by cycling are asphalt roads in rural areas that pass through residential houses, north asphalt roads that cross citrus plantations, west and south concrete rebate roads that cross plantations, west dirt roads that cross ravines, south asphalt roads that cross gardens. , the east asphalt road that crosses the ravine, the south dirt road and the east concrete rebate that crosses the village forest, the north asphalt road that crosses the orange groves and settlements to the parking lot. Based on the route analysis conducted with the tourism awareness group, the wiata cycling route can be presented as follows: 


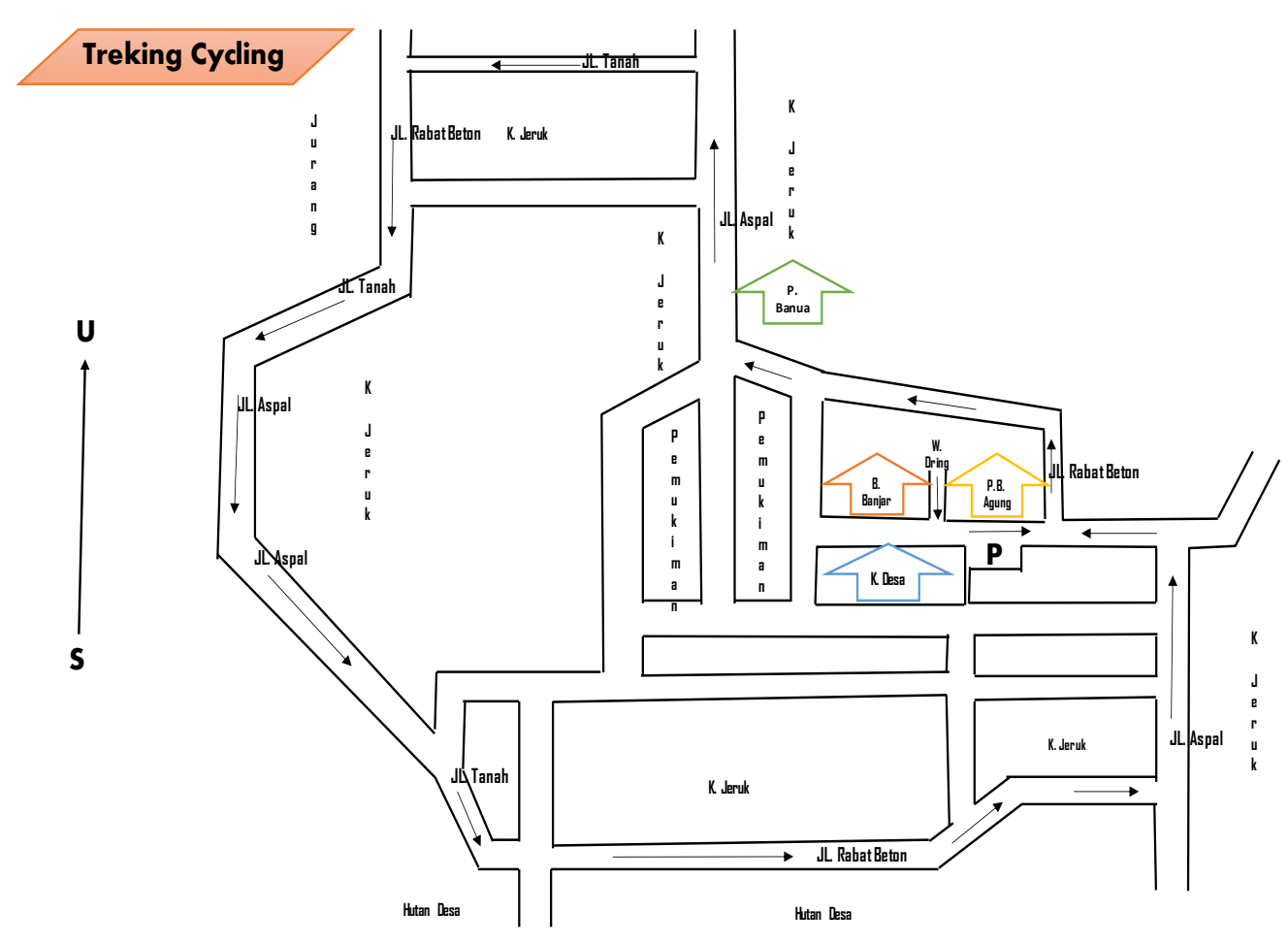

Figure 2 Cycling . Tour Route

The second stage is to determine the cycling tourism map by analyzing the roads that will be traversed by cycling tourists. For this reason, the analysis is carried out by tracing the roads that will be traversed by cycling tourists by bicycle. This is done to ensure that the cycling tour route that is made can be passed well by bicycles and is comfortable to pass. The results of direct observations and cycling are used to determine resting places, places to take photos and places to observe the activities of farmers who are working in the garden. Then make the drawing manually to determine the distance from the start line to the finish line. This manual image of the sycling tourist map then becomes a guide in making a computerized map to calculate the distance, travel time and direction of travel for tourists, including entering sycling tourism data on a google map, so that it can be easily seen by tourists who are going on a cycling tour in the Traditional Village. stupid. The cycling tourism map can be described as follows: 


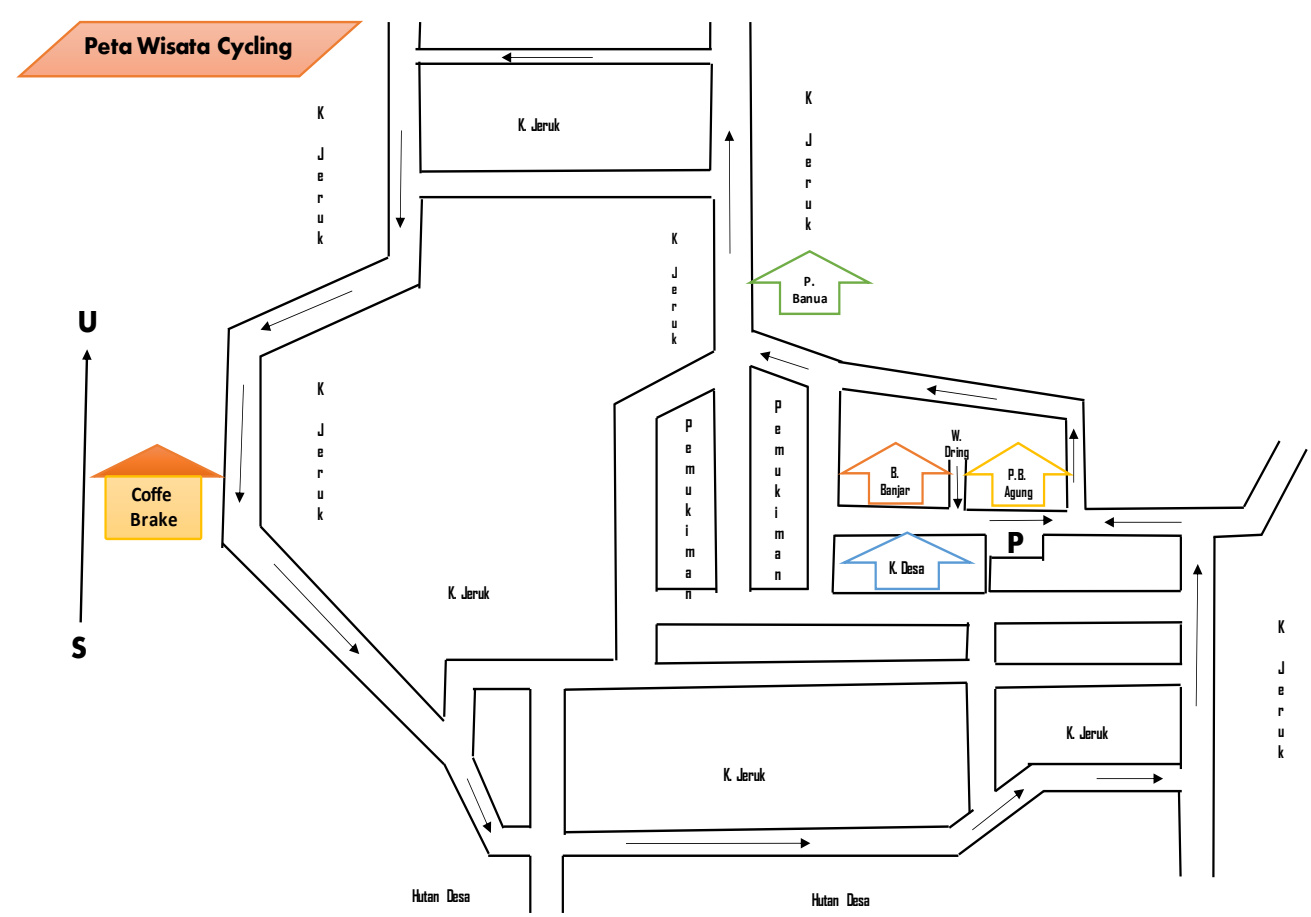

Figure 3. Cycling Tourist Map

The third stage is to determine the cycling tour package menu by conducting an appropriate cost analysis to enjoy cycling tours in the Bonyoh Traditional Village. The initial activity is carried out by determining what facilities will be obtained by tourists during cycling tours in the Bonyoh Traditional Village. Based on the analysis conducted by the tourism awareness group, the facilities that will be obtained while tourists are doing cycling tours are bicycles, mineral water, welcome drinks, snacks typical of the Bonyoh Traditional Village, orege juice drinks typical of the Bonyoh Traditional Village, guides, parking lots, public toilets, spots photos, agricultural activities, natural scenery and fresh air. There are facilities that are obtained by tourists that are economical and can be calculated easily as well as those that are natural, so that it is difficult to calculate economically but can be predicted according to public perception. Bike rental Rp. 20,000 per day, mineral water Rp. 5,000, welcome drink Rp. 5,000, a typical snack from the Bonyoh Traditional Village Rp. 5,000, orege juice drink typical of Bonyoh Traditional Village Rp. 5,000, guide Rp. 100,000, parking Rp. 2,000, public toilet Rp. 2,000 , free photo spots, free agricultural activities, free natural scenery and fresh air and a contribution to the Bonyoh Traditional Village of Rp. 5,000. Based on this calculation, for a group of 100 tourists, the fee to be paid is as much as Rp. 50,000. If there are 50 tourists, the fee that must be paid is Rp. 51,000 and so on. The facilities that will be obtained by cycling tourism are as follows: 


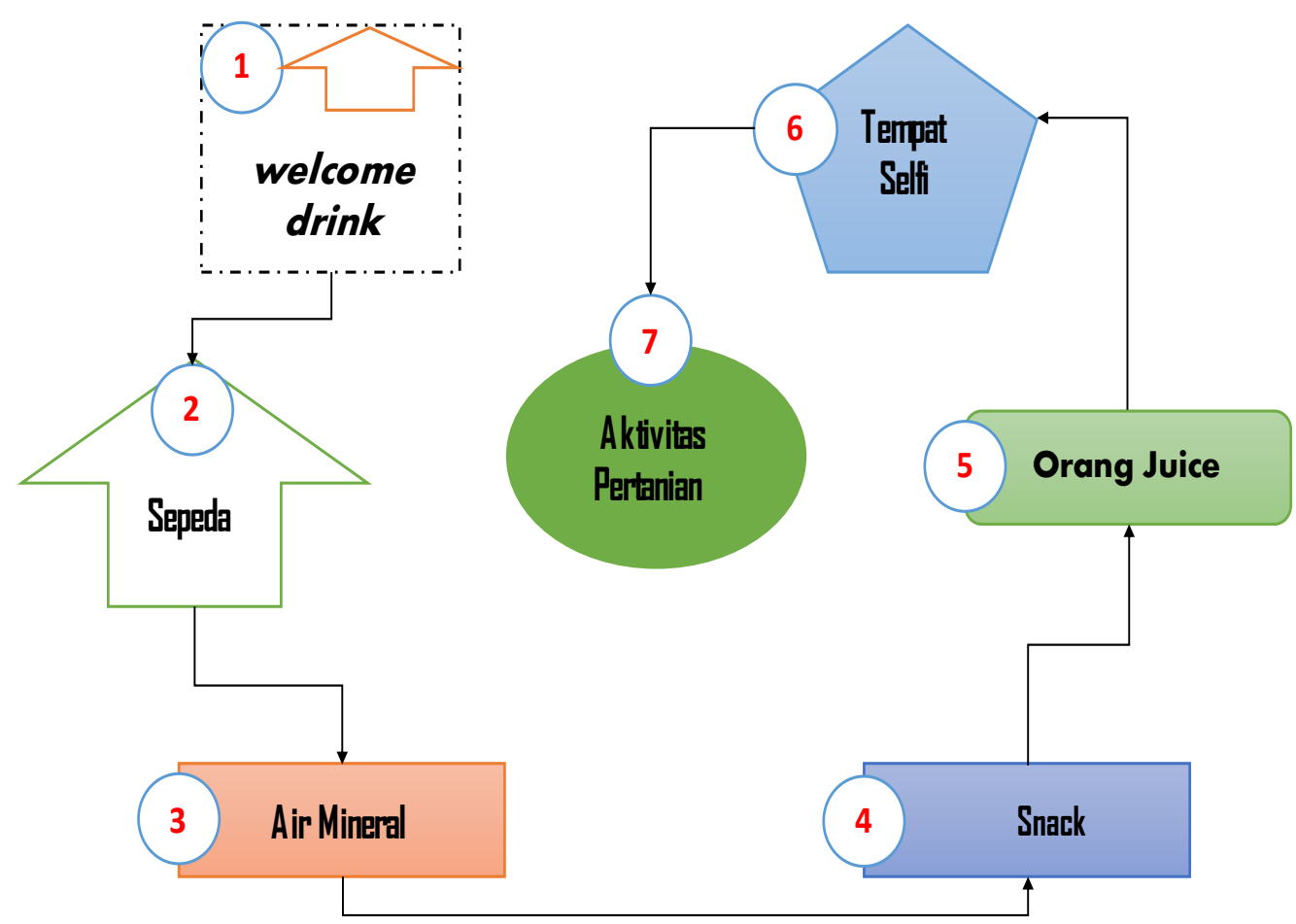

Figure 4. Cycling Tour Package Menu in Bonyoh Traditional Village

The fourth stage is to form a cycling tourism management structure in Bonyoh Traditional Village which is under the management of BUPLA (Baga Utsaha Padruwen Traditional Village). In connection with the formation of this cycling tourism manager, it is first analyzed about the competencies that must be possessed by the manager according to needs. Based on the analysis carried out, the competencies that must be possessed by cycling tourism managers are: (1) have the skills to use or ride a bicycle, (2) have the ability to communicate in Indonesian fluently and communicate using minor English, (3) have the will to work hard work in the team, (4) at least graduated from high school SMA/SMK or equivalent, (5) has a commitment to advancing the cycling tourism business, (6) members of the Bonyoh Traditional Village residents, and (7) at least 17 years old when submitting an application with proven through a birth certificate or identity card (KTP)/other identity. To select the cycling tourism business manager, several stages of activities were carried out, namely: (1) conducting administrative selection, (2) giving written tests, (3) conducting interview tests, and (4) skills 
tests. The structure of the cycling tourism business manager can be described as follows:

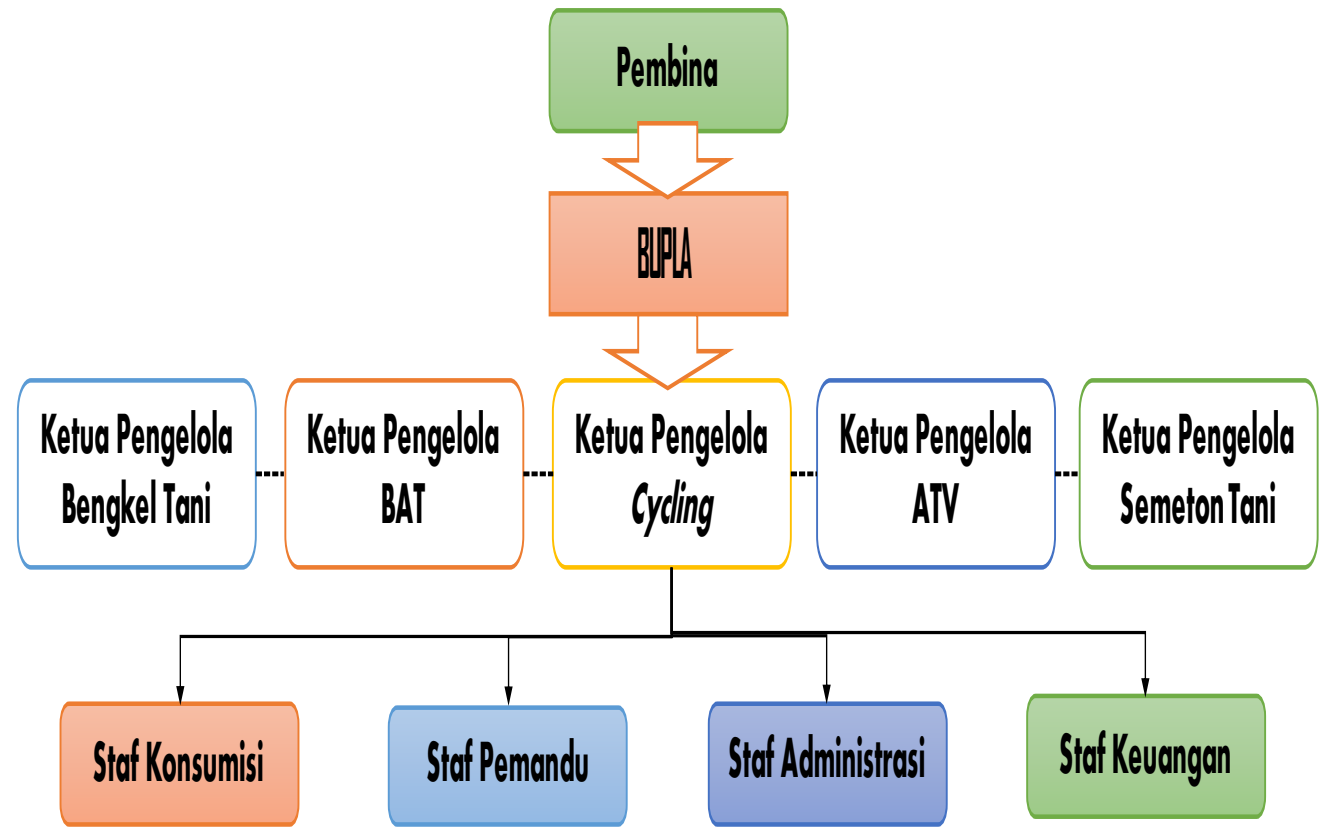

Figure 5. Cycling Tourism Business Management Structure in Bonyoh Traditional Village After going through the selection process as described above, a cycling tourism business manager will be determined in the Bonyoh Traditional Village. This cycling tourism business management group will be responsible professionally for managing the cycling tourism business from making a schedule of cycling activities, human resource management, financial management, maintenance of cycling tourism routes and facilities, providing consumption, to making accountability reports that will be submitted to the BUPLA manager (Baga Utsaha Padruwen (Indigenous Village) and Bendesa Adat as supervisors. In this regard, the management of the cycling tourism business will be given training and assistance in the management of the cycling tourism business, training in financial management for the cycling tourism business, training in making cycling tourism promotion media and training on promotion through social media for cycling tourism in the Bonyoh Traditional Village. To ensure the ability and skills of cycling tourism business managers, this training will be provided by academics from Ganesha Education University who have competencies in accordance with the needs of cycling tourism business managers. The recruitment process for the cycling tourism business can be described as follows: 


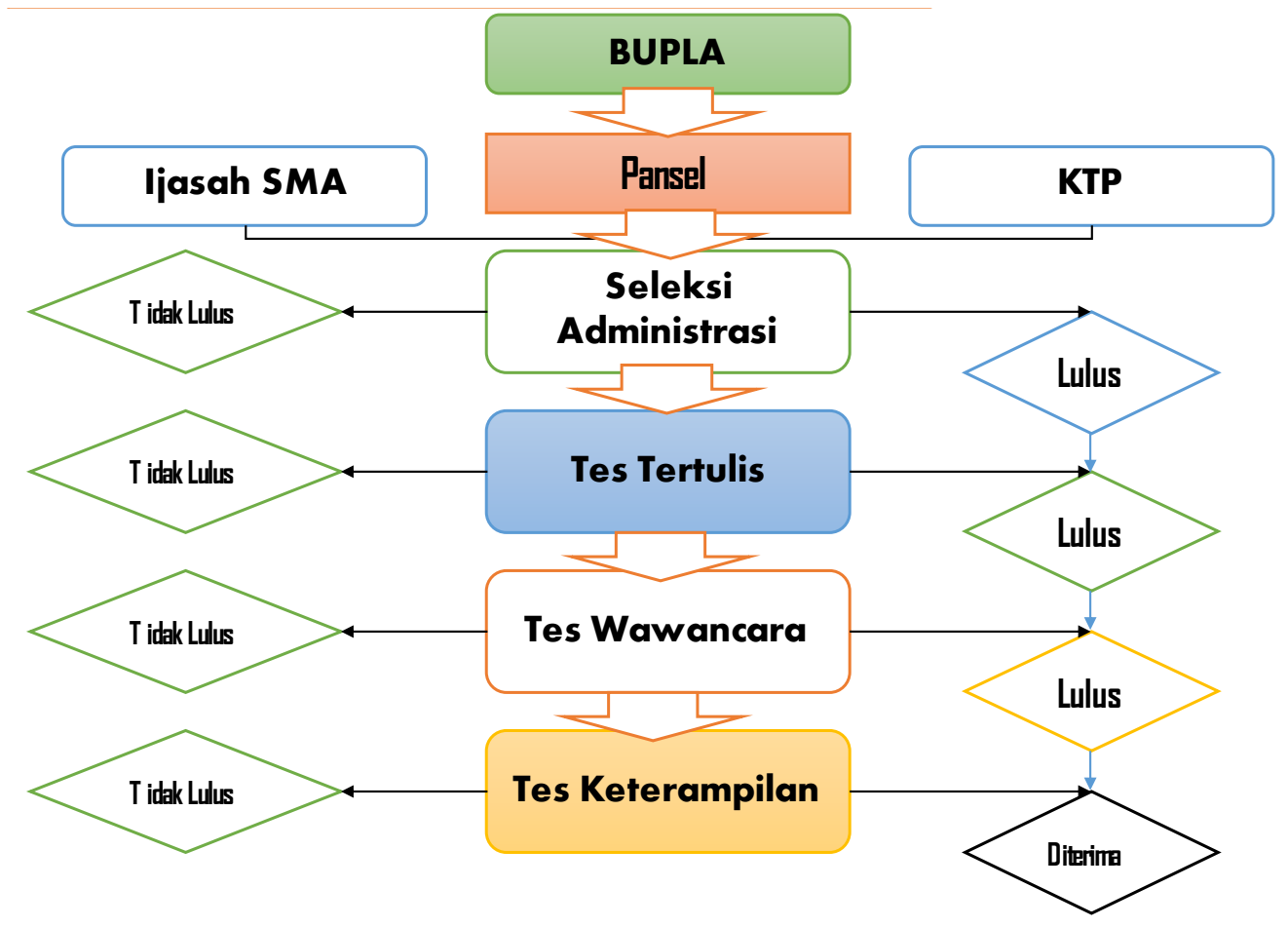

Figure 6. The Process of Selecting Cycling Tourism Business in Bonyoh Traditional Village

\section{Conclussion}

The decision-making process for developing a tourist village and cycling tourism business in the Bonyoh Traditional Village begins with the process of proposals from community members, discussing community proposals at small meetings (community leaders) and submitting decisions to small meetings to all communities to get input and approval. The development of a cycling tourism business in the Bonyoh Traditional Village is carried out in several stages, namely: (1) determining the route and analyzing the feasibility of the route, (2) making a cycling tourism map in Bonyoh Village, (3) making a cycling tour package menu in Bonyoh Village, and (4) establish a cycling tourism management structure in Bonyoh Village.

\section{References}

[1] Benuf, K., \& Azhar, M. (2019). Metodologi Penelitian Hukum sebagai Instrumen Mengurai Permasalahan Hukum Kontemporer. Metodologi Penelitian Hukum Sebagai Instrumen Mengurai Permasalahan Hukum Kontemporer, 3(2), 145-160.

[2] Duija, I. N. (2018). The Transformation of Character Values in Melampuhan Tradition in Bayung Gede Village, Kintamani, Bangli : An Ethno-Pedagogy Study. 2(9), 30-44.

[3] Laksmana, T. A., Rachmat, H., \& Tahir, R. (2020). Strategi Pengembangan Wisata Bersepeda Berdasarkan Karakteristik Motivasi Pesepeda Urban (Pada Grup Sepeda TOC Dan JGC-SCAM). Jurnal Pariwisata Terapan, 4(1), 73. https://doi.org/10.22146/jpt.54742

[4] Li, L., Kovalchuk, A., \& Tour, J. M. (2014). SnO2-reduced graphene oxide nanoribbons as anodes for lithium ion batteries with enhanced cycling stability. Nano Research, 7(9), 1319-1326. https://doi.org/10.1007/s12274-014-0496-x 
[5] Lucía, A., Hoyos, J., Santalla, A., Earnest, C., \& Chicharro, J. L. (2003). Tour de France versus Vuelta a España: Which is harder? Medicine and Science in Sports and Exercise, 35(5), 872-878. https://doi.org/10.1249/01.MSS.0000064999.82036.B4

[6] Mahagangga, I., Suryawan, I., Nugroho, S., \& Sudana, I. (2016). Pemetaan Jalur "Paket Wisata Pedesaan" Di Desa Wisata Penglipuran, Kecamatan Bangli, Kabupaten Bangli. Jurnal Udayana Mengabdi, 15(2), 1-6.

[7] Mezak, M. H. (2006). Meruy_Jenis_Metode_dan_Pendekatan_Dalam.V(3), 85-97.

[8] Qamar, N., Syarif, M., Busthami, D. S., Hidjaz, M. K., Aswari, A., Djanggih, H., \& Rezah, F. S. (2017). Metode Penelitian Hukum (Legal Research Methods). December, 176.

[9] Sanders, D., \& Heijboer, M. (2019). Physical demands and power profile of different stage types within a cycling grand tour. European Journal of Sport Science, 19(6), 736-744. https://doi.org/10.1080/17461391.2018.1554706

[10] Saputra, K. O., Mertasana, P. A., \& Sudarmojo, Y. P. (2019). SISTEM KESINOMAN BERBASIS ANDROID. 18, 1-7.

[11] Suastika, I. N., et. al. (2019). Traditional Life of Bayung Gede Community and Its Development As Cultural Attraction. 3(1), 108-121.

[12] Wahyuni, D. G. S. I., \& Anom, I. P. (2019). Pemberdayaan Kelompok Masyarakat Dalam Pengemasan Paket Wisata Pedesaan Di Desa Pelaga Kecamatan Petang Kabupaten Badung. Jurnal Destinasi Pariwisata, 6(2), 210. https://doi.org/10.24843/jdepar.2018.v06.i02.p02

[13] Wirawan, K. (2016). Wisata Sepeda Dalam Mewujudkan Pariwisata Berkelanjutan Di Sanur. Jurnal Master Pariwisata (JUMPA), 2(2008), 1-16. https://doi.org/10.24843/jumpa.2016.v02.i02.p01 